\title{
Watercolors Awash in Crayoned Responses: Teaching Narrative in Arts-based Praxis
}

Cynthia M. Morawski, Ed.D.

University of Ottawa

morawski@uottawa.ca

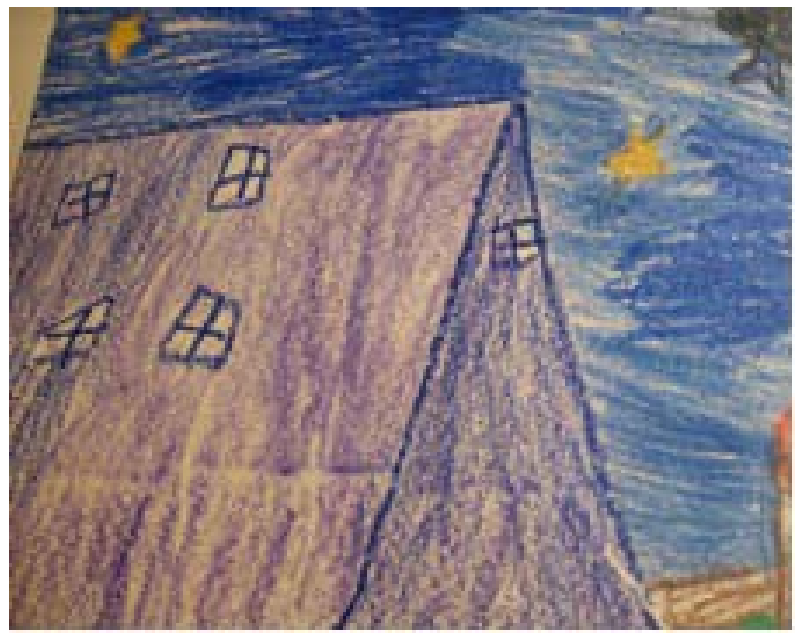

\begin{abstract}
I work in literacy education, encouraging teacher candidates to experiment with the arts to make a novel come alive for adolescent readers. Part of my research agenda, which is intertwined with my teaching, seeks to make sense of the question: What are the effects of arts-based learning on the teacher candidates' theoretical and classroom practices? To first consider the above research question from my own pedagogical perspective, I draw on my earlier recollections (Adler, 1958) of arts and classroom living using the methodology of narrative inquiry - the study of the ways humans experience the world via the construction and reconstruction of their own stories (Connelly \& Clandinin, 1990). Informed by my teaching narrative, crafted in the backdrop of remembered times, I venture forth to address


the effects of arts-based learning on the teacher candidates' theoretical and classroom practices. A more informed construction of our recurring narratives, rekindled by the illumination of early recollections, will play an integral role.
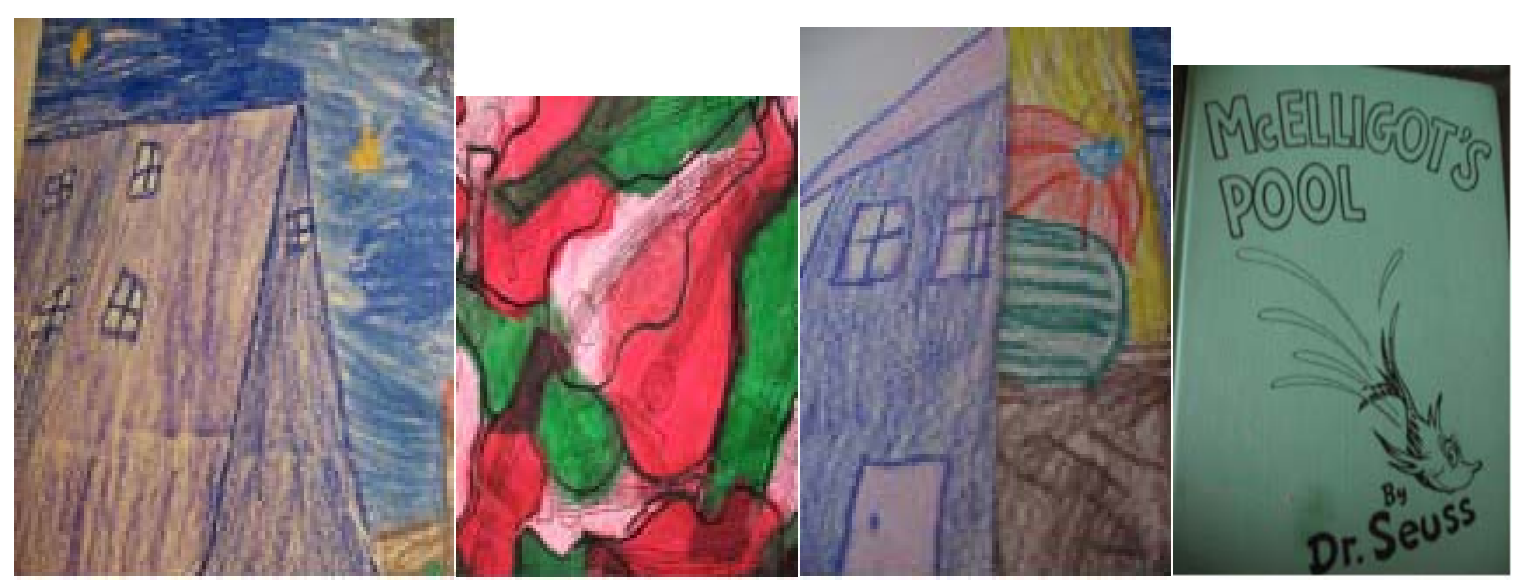

\section{Water colors awash in crayoned responses: Teaching narrative in arts-based praxis}

I work in literacy education, preparing teacher candidates to teach language arts to students in grades 7-10. Making generous use of content areas and the multiple sign systems that they offer, I strive, as Noddings (1984) advocates, to lay out education "along the entire range of human experience so that students may make multiple and potentially meaningful contact with it" (p. 191). The words of math counter our poetic expressions. The forms of geography landscape our thoughts. The science of computers deprogram our prose. For part of our course, I encourage teacher candidates to experiment with the arts to make a novel come alive for adolescent readers in the intermediate classroom. Body biographies (Underwood, 1987), whirligig installations (Morawski, 2006), and graffiti walls (Costello, 1993) are some of the arts-based applications that we use to study such fictional works as The 
Outsiders (Hinton, 1967), Whirligig (Fleishman 1998), and True Confessions of Charlotte Doyle (Avi, 1990).

Part of my research agenda, which is intertwined with my teaching, seeks to make sense of the question: What are the effects of arts-based learning on the teacher candidates' theoretical and classroom practices? In anticipation of working with teacher candidates to answer this question, I acknowledge pertinent research literature (Jersild, 1955; Laird, 1988; Leggo, 1995) that emphasizes the critical role that teachers' storied pasts play in the reconstruction of their pedagogical presents. In particular, Dinkelman (2003) states that "self study by teacher educators...promotes reflective teaching by the very example it sets" (p. 11). Therefore, before asking teacher candidates to weave the threads of their own recurring narratives into the discourse of arts-based praxis, I heed Connelly and Clandinin (1988) who posit, "if you understand what makes up the curriculum of the person most important to you, namely, yourself, you will better understand the difficulties, whys, and wherefores of the curriculum of your students" (p. 31). Moving along my research continuum on the Adlerian concept of early recollections in literacy education, (Gilbert \& Morawski, 2005; Morawski, 1995; Morawski \& Palulis, in press), I first draw on my earlier experiences (Adler, 1958) of arts and classroom living using the methodology of narrative inquiry - the study of the ways humans experience the world via the construction and reconstruction of their own stories.

\section{The memory of narrative inquiry}

The valuable interdisciplinary contributions of Alfred Adler's precursory postmodern theory can be seen in the work of such individuals as Glasser, Rogers, Ellis, Frankl, Maslow and Hawes (Mosak, 1995; Watts, 1998; Watts \& Pietrzak, 2000). Education, however, was 
always a primary focus of his work (Grey, 1954). One of his first and most important works, which focused on child guidance and education, is entitled Physician as Educator (Cosner, 2007). In particular, Adlerian theory, which underscores the integral role of holism or unity in understanding life stories (Adler, 1927,1930) tells us that memory is a creative enterprise, a metaphorical composition of personal meaning patterned from the interpretive selections of living perceptions_-“an encoded narrative of the present” (Hestor, 2004, p. 340). Schneider and Stone (1998) emphasize that Adler's notion of early recollections, particularly in relation to lifestyle, finds a natural harmony with narrative practice. Furthermore, Maniacci, Shulman, Griffith, Powers, Sutherland, Dushman and Schneider (1998) comment that early recollections offer insight and change in the construction of narratives as agents of life style assessment. In essence, early recollections reflect present attitudes, beliefs, and actions - the story of my life now (Ansbacher, 1947; Verger \& Camp, 1970). Presently, I turn an Adlerian lens on my narrative to better prepare me to work collaboratively with teacher candidates on their narratives in our multi-layered journeys of arts-based praxis.

\section{Recollecting narrative present}

In Adlerian practice, specific theoretical and practical supports exist for the collection and understanding of early recollections (Eckstein \& Baruth, 1996; Sweeney, 1981), which play a primary role in narrative inquiry. Recollections, often retrieved in sets of three, center on the physical and emotional contents of specific events, as opposed to general statements. Adler (1932) maintains, "One...recollection is sometimes not clear enough. You must draw on further recollections...to find what they have in common" (p. 198). Moreover, Adler (1927) asserts, "There are no indifferent...recollections" (p. 50). That is, contained 
within the selected recollections is the resonance of an individual's style of life. As Pearson and Wilborn (1995) so aptly convey, early recollections are subjective starting points, the beginning of one's autobiography. Although, the memories I select today, may not necessarily represent where I will be in eight months or eight years, it is the potential that the selected texts have for reflective work in the recurring present that is most significant.

Retold in the following pages are the recollected stories of three school experiences that I have cast to represent pieces of my teaching narrative. In particular, I take into account the part that the stories assume in the construction and implementation of my language arts methods classes, particularly in relation to arts-based learning. The first recollection, which occurs in the second grade, concentrates on my aesthetic response to a picture book reading. The second one, taking place in the same classroom, revolves around the teacher's disapproval of the color of my dream house. Fast forwarding to high school, the third recollection comes alive in an art class, where I take up pen and India ink to render the color of language resonating from the strings of many guitars. Not intending, as Abbs (2003) states "to prescribe settled...meaning" (p. 14), I acknowledge the subjective nature of memory work, while I retrieve from the past to recreate my arts-based teaching narrative in the present. As Kirby (1991) expresses, "memorial experience (recollection) is not simply of the past; it is, as we had said, the past for me now, and this qualification makes a considerable difference" (p. 24).

Recollection one: My first recollection of learning and teaching transpires in my primary classroom, where the teacher invites us to illustrate our responses to a picture book reading. 
As a member of the group, I enact my own depiction, responding in aesthetics to the elements of a Dr. Seuss (1947) story. I am six years old.

After reading Dr. Seuss' latest work, McElligott's Pool, our teacher walks to the back wall and asks us to clear off our table desks. She reaches into the supply cupboard and

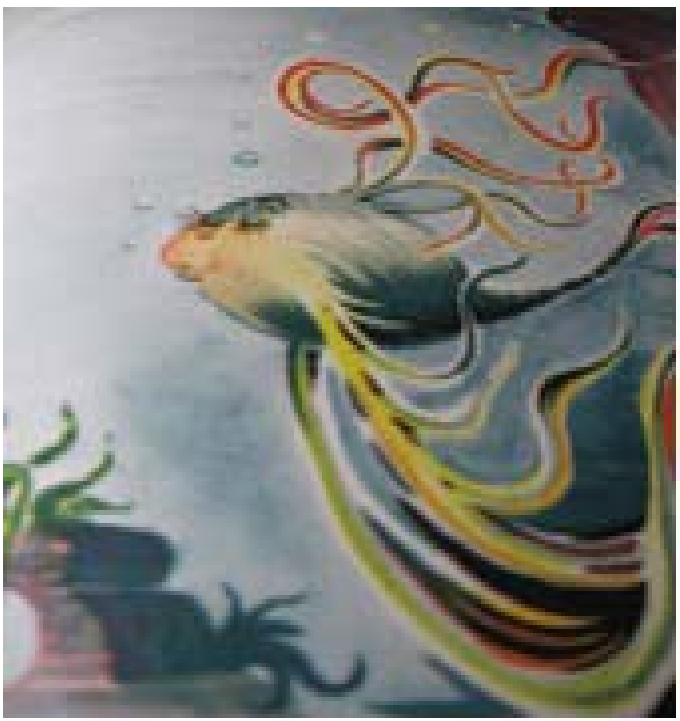
takes out a pile of large sheets of creamcolored paper, watercolor cases, and glasssize containers. We welcome our supplies. Our teacher then invites us to paint our own version of McElligott's Pool, complete with the different kinds of fish that you might catch in this pool, which has underground connections to a river and the sea. After she

instructs us to wet the entire surface of the paper, I dip my brush into the squares of color and possibilities emerge - pencil fish, apple fish, and even a more flamboyant edition of the one who likes flowers. I am immersed in my creations that seem to flow from the tip of each brush stroke. Occasionally, our teacher asks us to share our ideas. Time stands still. Ideas spill out and wash into the sea. I am connected-my mind and emotions entangled.

Recollection two: Interestingly, my second recollection takes place in the same classroom, during the same year as the first recollection. In this particular event, learning and teaching emerge in the form of a two-storey red pencil box, complete with an assortment of red thick pencils, flat fat crayolas, and a pink rectangle of an eraser. These are tools to turn paper into 
the patterns of an April sun, settling on the windows of a classroom afternoon. I am now seven years old.

After running under a canopy of green ginko leaves, I enter the classroom and open my two-storey red pencil box, couched on the cover of a group one reader. Maple tables and chairs square off around me as our teacher instructs us to draw a neighborhood scene. I select a flat fat crayola and color my dream house purple. A stunning New England cape cod, shaded by a pink dogwood tree. A pumpkin patch sits next to a slate path. A view of The Sound peeks through marshy reeds. With unsuppressed excitement, I rush to show my teacher. I am told to redo my

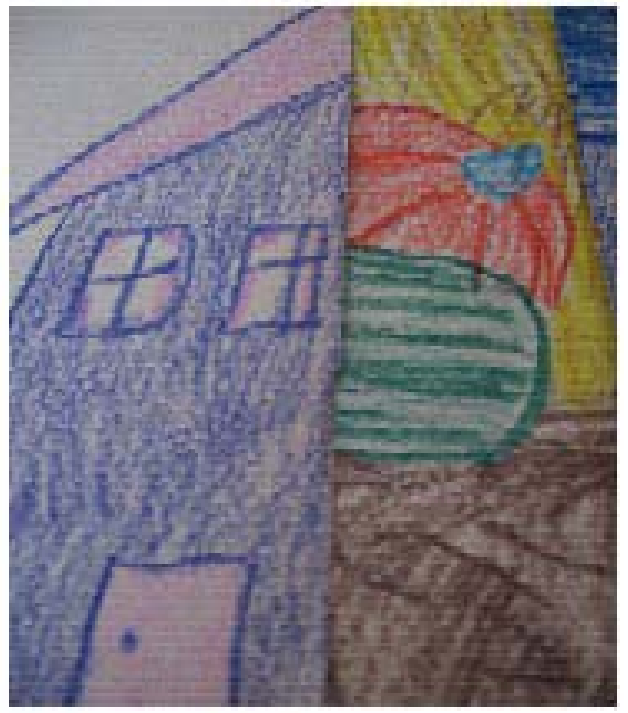
drawing. "There are no such things as purple houses.” I am confused, puzzled, and surprised by the words of this teacher - the same one who encouraged us to invent our own fantasia of sea life. As authoritative discourse casts shadows across my drawing, I conjure up the template for my house — an existing plum-colored Victorian cottage, adorned by a weather vane and two window boxes overlooking a lilac tree. It stands two miles away from our elementary school.

Recollection three: Moving forward almost a decade in time, my third recollection centers on an art assignment, given by an encouraging and dynamic teacher. The open-endedness of 
the instructions allows us to play with the possibilities of tissue paper, color, ink and form. I am sixteen years old.

I walk up two flights of stairs, turn toward the west, and sit down in a crowded art room. As the class settles down in the aftermath of a dozen overlapping conversations, we are

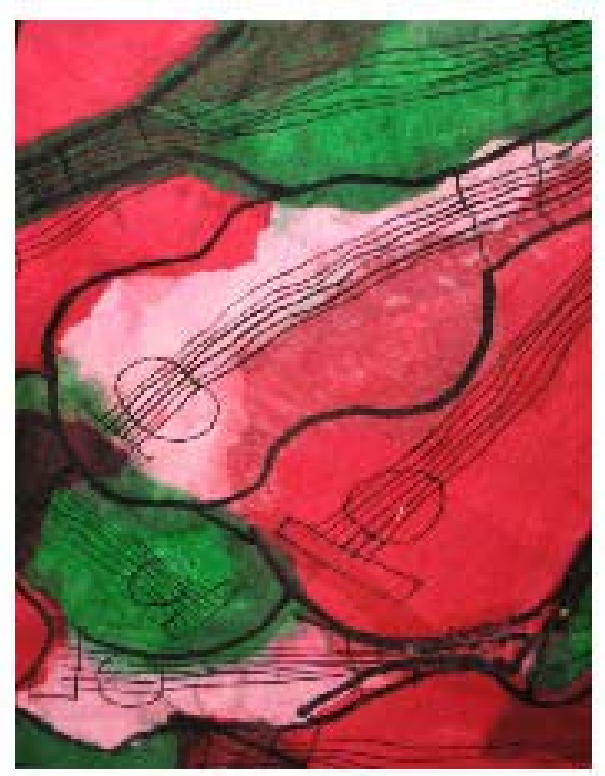
introduced to the next assignment - a tissue paper collage of mixed media capturing a representation of personal interest. I begin by pulling three pieces of paper from a pile heaped with colors of variegated hues. While arranging and gluing the torn edges of red, green and rose, I hear the reverberations of twenty acoustic guitars. Folk music plays the sounds of commitment, revolution, concern, unison and refrain.

Summoned by Ravi Shankar's sitar, I work the nib that delineates the shapes of many guitars stringed in the black ink of a raga's hum. I am in a Csikszentmihalyi (1991) flow. I concentrate fully on my work before me. Suddenly, without warning, I reenter the reality of the classroom as my teacher encourages me to continue. In the end, I receive a first prize in the annual school art show.

\section{Recollecting narrative of arts-based teaching}

Short, Kaufman, and Kahn (2000) tell how "readers understand the new by searching past experiences with... life to find connections that will bring meaning to the current text" ( $\mathrm{p}$. 165). I dig and sift through my sites of recollected field texts, looking for recurring 
connections into the inquiry of my present arts-based practice. Without hesitation, I settle on the three school events, while embracing Alexander's (1971) comments "Here are the materials that have been meaningful to me, here I am, share us..." (p. xi). Acting on Adler's idiographic approach to signifying early recollections (Ansbacher, 1947), I now respond to my teaching narrative of arts-based learning, where I pry open my praxis with a palette of paint, broken chalk, brown paper, crayons, fabrics, and a crateful of glue. Immersed in these materials, the teacher candidates work with me to stretch the language arts curriculum with artful formats of lived inquiry (Eisner, 1992). For part of our time together, our methods classroom becomes a community portfolio, a bohemian playing field of curricular possibilities, as we struggle to disrupt and deconstruct language arts education via graffiti walls, body biographies, resolutions scrapbooks, and whirligig installations. Embracing Adler's (1958) belief that the individual is both the picture and the artist, I presently review my three recollected texts. First, one at a time, I place them on the ledge of my easel, located in the midst of my teaching narrative. Then, as a gallery arrangement, I consider their meaning collectively.

\section{Response to recollection one: a watercolor depiction of McElligott's Pool. Maxine}

Greene (1991) challenges us that "the arts offer opportunities for perspective, for perceiving alternate ways of transcending and being in the world" (p. 32). Although I have always carried within me the sights and sounds of my first memory, it was not until now that I have recognized its actual connection to the theoretical and practical formation of my teaching narrative. Warren (1982) contends, recollections, which contain indications of current views, beliefs, and practices, "are not due to chance, but reflect the selective memory process of the 
individuals" (p. 224). While the majority of my second-grade learning experiences proceeded along a more conventional path of subject separation, I did chose one that featured the application of the arts to a content area—language arts. In the immediate moments after rereading my experience of a second grade response to Dr. Seuss, I am struck by a bolt of "aha" (Mosak, 1995, p. 75). Encapsulated in memory right before me is my first school encounter with the integration of the arts and literature.

Upon reflection, I realize that this remembered event illustrates what Short, Kauffman, and Kahn (2000) describe "as in the process of taking our ideas public through a sign system, we create new ideas that go beyond our original conceptions" (p. 169). Through my artistic response to McGilligott's Pool, I had moved beyond a passive comprehension and entered into what Rosenblatt (1980) refers to as a "lived-through experience" (p. 280). The opportunity to react to a story with watercolors and crayons inspired me as I worked with my classmates to generate new forms of sea life and related expressions and representations of language arts. Although I do not have my original water color drawing, the book, McElligott's Pool, which I bought soon after the teacher read the story to the class, sits in my bookcase, as a reminder of the pedagogical possibilities of artsbased learning in language arts education.

From an Adlerian perspective, the first recollection can be the most significant, providing valuable insight into the individuals' views of life tasks and their participation in them (Ansbacher, 1947; Clark, 2002; Pearson \& Wilborn, 1995). As I consider my text, I am 
pulled toward such words as "immersed in my creations", "ideas spill out", and "mind and emotions entangled". I now realize that my experience, in which I encountered flow, connection, and promise of the imagination via artistic response to a work of children's literature, prepared the foundation for my teaching praxis. I settled on one of those times that my primary school teacher provided the ingredients and established an encouraging atmosphere in relation to content-area learning. In response, I embraced an opportunity to use both language and the arts to represent and express my ideas and expand my understanding of the world. To quote my first recollection, "I am connected."

When Sullivan (2000) encouraged pre-service teachers to observe student difference through poetic lenses by getting "under the skin of the other..." (p. 225), she connected her grounding in attention with her mother's love of salty estuaries and skill at poling from sunlight into drawbridge shadows with the sun burning "at her shoulders in its slow passage across the sky" (p. 212). "What I do remember" Sullivan recounts "is so deeply embedded in experience that it has entered my ways of thinking and perceiving, my very way of being..." (p. 222). Like Sullivan, my own recollection has lodged in my current sites of work, where precarious piles of adolescent novels intersperse the stuff of classroom practice.

The Outsiders. Whirligig. True Confessions of Charlotte Doyle. Wooden cherry dowels. Wrinkled rolls of translucent wrap. Crayon boxes stacked on foolscap pages. Found sheets of corrugated crepe. With all of this and more I reenact, what Pillemer (2001) describes as "active, persistent influences" (p. 126) of my first memory, which continue to "inspire, direct and sustain my actions and beliefs long after the original occurrence" (p. 124). Taking up my variegated palette of arts-based pedagogy, I strive and struggle to offer teacher candidates another view, another perspective, that the content, form and functions of 
the arts can provide. To create critical openings for studying The Outsiders, I paper the classroom wall on which teacher candidates draw, scratch and scribe the multiple personas of each character's life. Markers, crayons, and pens ask, state and answer, evoking quotes, symbols and pictures associated with the adolescent lives in the story.

To rethink questions of gender and power surging through True Confessions of Charlotte Doyle, the teacher candidates and I work together to capture Charlotte's biography within life-size outlines unrolled on scrolls of brown paper. A heart. A mind. A body begins to speak in split images of yarn, paper, fabric, and glue. Words, phrases, and quotes accent, underscore, and embellish. Lace and jute. Deference and struggle. A pink bonnet and weathered skin. A coward and a hero. Four distinct texts composed in the life of Charlotte Doyle.

To reconsider the journey of retribution that Brent, the protagonist in Whirligig, must follow after killing a teenage girl in an alcohol-related car accident, I supply the class with the basic mechanisms and materials to reconstruct a whirling structure. Each group of five rebuilds symbolically one of the segments of Brent's trip in which he designs and erects a whirligig to celebrate the deceased girl's life. Maps, hearts, pictures, signs, directions, and other expressions define each structured text, which then becomes the centerpiece of a reader's theatre. For these three works and more, we immersed ourselves in recurring effects of an arts-based pedagogy, "the form through which insight and feeling can emerge in the public world" (Eisner, 1992, p. 595) of novel study for adolescents.

\section{Response to recollection 2: reprimand of the purple house. Verger and Camp (1970)} claim, "while the earliest recollection is often the single most useful recollection...the three 
earliest recollections, presented in chronological order are frequently even more helpful" (p. 514). In contrast to my first remembered experience, my second one, which happens in the same classroom, begins with the creation of my neighborhood scene and ends with a reprimand from my teacher who declares, "There are no such things as purple houses." The impression as a whole, Adler (1956) contends, "includes much more than the experience, which has been clothed in words" (p. 214). As Fredericksen (2000) states, "Educators make a serious mistake if they

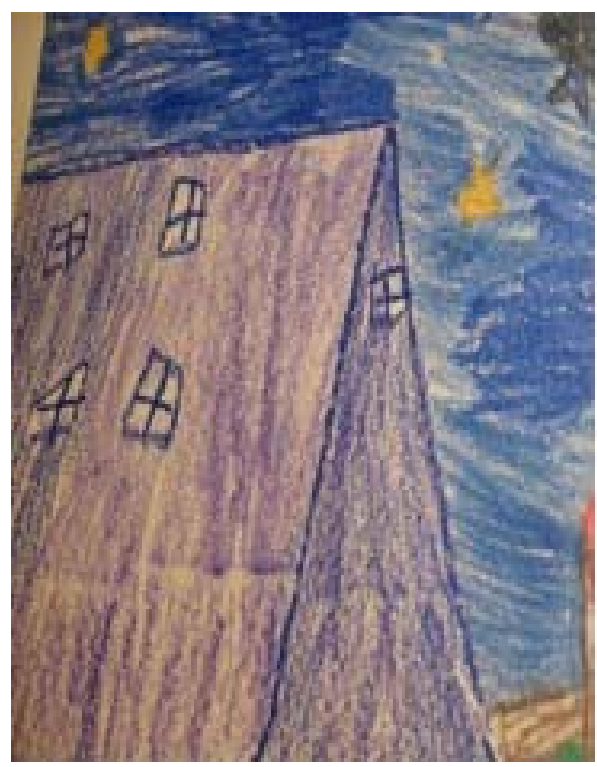
believe that...silence means acquiescence" ( $p$. 304). At seven years of age, I did not have an adult's cognitive capacity, vocabulary and power to critically reflect and act on my teacher's words. I did, however, recognize their personal significance, which now appear in my desire to extend the range of meaning making in the language arts classroom, particularly in relation to novel study for adolescents.

Searching for meaningful connections between color and early memories, I locate Clark (2004) who maintains, "It is difficult to conceive life without a multitude of color properties in dwellings, attire, and in lavish colors present in nature" (p. 143). Responding to his statement, I begin to understand my recent fascination with the life and works of Georgia O'Keefe, who in the wake of the critic's disapproval of her bold and brilliant use of color, displayed courage and conviction. On one occasion, when, in jest, she painted the burned brown boards of a shanty as murky and drab, the critiques remarked, "She's getting down to 
real color now" (Riley, 1995, p. 170). "That was my only low-toned dismal-colored painting" (p. 33) said O'Keeffe (1976), who affirmed that "The meaning of a word - to me - is not as exact as the meaning of a color" (p. 1). This independent artist inspires me as I strive to apply the arts to expand teacher candidates' capacity to conceptualize and construct meaning in the today's classrooms, fraught with an exclusionary agenda of standardization and testing (International Reading Association, 1999a; 1999b). Pulling from such theoretical spaces as reader response (Rosenblatt, 1978) and creative process (Amabile, 1989), I invite teacher candidates to take advantage of the entire spectrum of curricular possibilities of learning for all students, in concert with critical reflection and action. After all, purple is a color of mingled red and blue.

Feeling like a co-conspirator of the teacher autobiographer Hayden (1995), who, at the age of nine, recalled how a teacher's confiscation of a written piece of her work, compelled Hayden to write for the rest of her life as "an internal, almost autonomic activity, like circulation...that happened simply as a part of me" (p. 44). That early memory, Hayden remembered, “...proved a powerful, if somewhat unusual education... which in turn allowed me a greater general acceptance of difference" (p. 45). In his work on multiple subjectivities and developmental difference, Smith (2001) questioned the singular written discourse on research dissemination, while advocating the use of multiple textual formats, such as poetry, drama, and fiction to convey knowledge and reconstruct new ways of understanding. In my own methods classroom, rather than confining the teacher candidates' responses and engagements to a single mode or color of expression, I encourage them to diversify their thoughts and feelings by way of multiple forms of representation, and, in the case of novel study, arts-based formats. 
For a portion of our arts-based novel study, I guide the teacher candidates in critically responding to pertinent issues, such as adolescent identity and familial influence, in journals constructed from recycled cardboard bound together with kite string and tapestry needles. Words, symbols, and images become our means of communication as we debrief in groups and whole-class conversations. We study and design post cards, which emerge as containers for the various messages and locations of characters' coming-of-age journeys. Within our original and collaborative scripts of reader's theatre performances, we address pertinent issues in adolescent life, ranging from teen suicide to sibling competition, in relation to selected scenes of our novels' settings.

Response to recollection 3: reverberations of twenty acoustic guitars. My third and last recollection materializes in the setting of a secondary school art class, where I move backward and forward in between what Maxine Greene (1995) refers to as a lived past and some future possibility. Immersed in a state of flow emanating from the vibrant colors of 120 strings, my blending of sight and sound receives encouragement and recognition from my teacher as well as referees, who have come to jury the school art show. Confirmation abounds - there is more than one way to

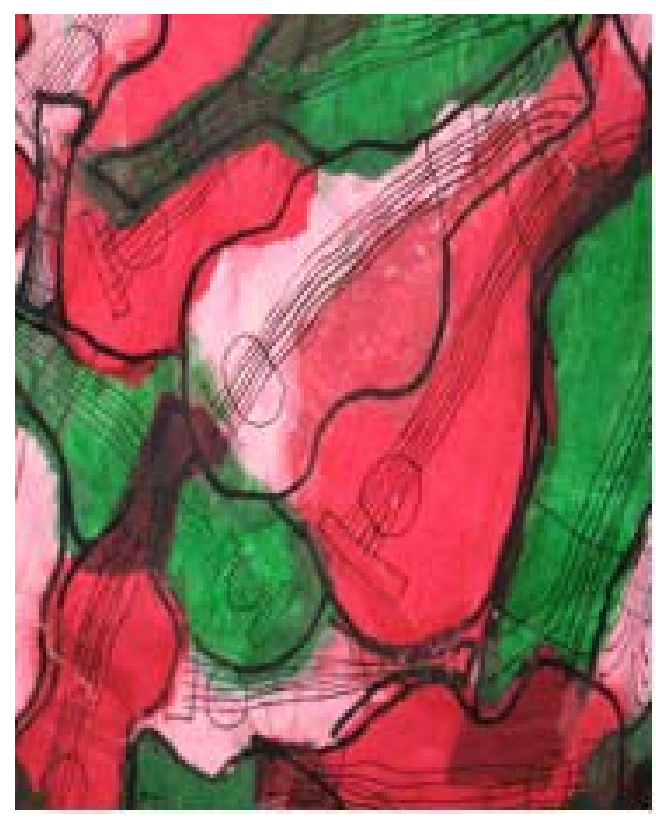
express and represent the aesthetic — the fusing of "cognitive and affective elements of consciousness" (Rosenblatt, 1980, p. 388). Lyrics, emotions, timbre and political positions 
appear in the varying silhouettes of inked guitars, defined by tissued textures of reds and greens and rose. Reflecting on this incident in the here and now, I instantly recognize my artwork as an example of transmediation—movement between and among sign systems (Leland \& Harste, 1994, p. 340). In my case, I took the political views and feelings of my high school life and recast them as a personal collage representing my impression of an unsettled and changing time.

In Boardman's (1991) study on the relationship between teachers' educational histories and their current teaching practice, three college teachers critiqued their past learning experiences embedded in anonymity and competition, to understand better their current teaching practices immersed in community and diversity. Their sense of the past Boardman says, "does not 'pull them back,' but it provides ways of questioning what they're doing now" (p. 7). Situating myself in a similar process of reflection, I come to acknowledge the integral role that transmediation assumes in helping teacher candidates make novels accessible to a diversity of adolescent learners. We undertake character analyses, description of setting and plot summary in assorted forms of communication from sculpture to collage. In turn, the teacher candidates construct their own arts-based expressions of personally selected novels and related works. Disappointments and desires of the colorful characters found in the text of The Great Gatsby emerge in the line drawings of pictured road maps of life. The struggles of a teen challenged by physical disabilities, portrayed in a recent film entitled Rory O'Sheas Was Here, surface in written profiles featured in a proposed high school newspaper. Propaganda, embedded in the layers of dialogic entitlement in the novel Animal Farm, become expressed in political posters featuring the hidden agendas of government policy. Leland and Harste (1994) state, "Movement between and among 
communication systems provides the opportunity for new perspectives on our knowledge and, hence, for the expression of an expanding range of meaning" (p. 340).

A collective retrospective. Aligning with Adler, Kirby (1991) proposes, "the material of recollection is analogous to archaeological finds that still require interpretation for their precise temporal location and sense" (p. 23). A watercolor awash in a crayoned response to McGilligott's Pool. A purple house standing by the undertones of a teacher's remark. A collage stringed in the colored reverberations of twenty guitars. When personally arranged and viewed collectively, the contents of individuals' recollections can offer a range of understanding concerning their recurrent perceptual orientations and responses to life tasks.

In the area of work, my review of three selected recollections provides me with nuggets of relevant material to make sense of my current teaching narrative. Abbs (2003) advises teachers to "begin where you are, think out of your existence, there is no need to hide” (p. 6). Placing myself in the vulnerable space of private and public scrutiny, I observe three common threads that run through each storied event. Multiple means of communication. Subject integration. Aesthetic response. As the examples of my praxis included in the above responses to my three recollections show, each one of these elements pervades my teaching narrative performed in the pre-service agenda of arts-based novel study for adolescent learners. Paper, paint, glue, ink, pens, glitter, and chalk, crafted into the multiple texts of aesthetic forms - graffiti walls, whirligig installations, body biographiescollude to make meaning in fictional realities-The Outsiders, True Confessions of Charlotte Doyle, Whirligig — and more. Geography, post cards, History, time lines, Media Studies, 
images of popular culture, Science, rotating mechanisms, all integrated with the brush of artsbased learning.

Concurring with Eisner (1992) who affirms, "the arts provide the conditions for awakening to the world around us" (p. 10), I integrate the arts-based experiences of my past into the teacher education curriculum of my present. Using our pre-service class as a laboratory of aesthetic opportunities for arts-based learning, I encourage teacher candidates to make novel study more accessible to all adolescent learners. To ground our practices in a foundation of "expansion and revision" (Greene, 1991), I braid our sessions together with such relevant theories as transactional literary analysis (Rosenblatt, 1978), pluralities of persons (Greene, 1991) and multiple intelligences (Gardner, 1999). Each of these theoretical workings opens up education to multiple means of content and form, from role-playing to painting to dance.

Leland and Harste (1994) state that " a good language arts program is one that expands the communication potential of all learners through the orchestration and use of multiple ways of knowing for the purposes of ongoing interpretation and inquiry into the world" (p. 339). In the preceding pages, I have incorporated references to the recognized work of many arts-based advocates such as Rosenblatt (1980), Greene (1995), and Short, Kauffman and Kahn (2000). Numerous others, who also promote the generous use of the arts in all areas of the curriculum, including language arts, continue to influence my praxis. Murata (1997) and her colleagues tackle the intricacies of social structure found in Steinbeck's The Pearl by studying Mexican muralists and constructing pastel triptychs. Whitin (2002) enters into literary interpretation with her grade six students who show different meanings of a story by sketching lines, colors, shapes, symbols and pictures. Hynes 
(2003) chronicles the case of a grade 7 student who finally understands written stories by drawing — the essence of his learning style. Buckelew (2003), Bussert-Webb (2001), Caswell (2005), Gilles, Andre, Dye, \& Pfannenstiel (1998), Marlett (2004), and McKay \& Kendrick (2001), are further examples of those who have encouraged me to open up pedagogical spaces of art-based learning in novel study for adolescent learners.

According to Short, Kaufman, and Kahn (2000), "many adults are uncomfortable with some... sign systems, but that is the result of a lack of exposure to, and use of, those systems in school" (p. 169). In the arts-based study of adolescent novels, where teacher candidates' responses to artistic sign systems can range from resistance to reception, selfreflection is a critical element. Harner \& Romer (1992) emphasize that "our vulnerability in breaking new ground and developing new ways of teaching and learning makes us pause and reflect back on earlier moments of discovery and connection" (p. 23). Querying former times, while learning language arts anew, furnishes opportunities for future teachers to interrogate and move beyond the way they were taught (Britzman, 1986), toward the way they can teach (Thorpe, 1987). An integral piece of this process is the recurring study of self that teacher educators bring to their methods classrooms. Dinkelman (2003) offers, "Simply put, students learn reflection from watching their teachers reflect" (p. 11). While sharing ongoing reflections of my own teaching praxis, including the recurring influences of the past, I am more present to encourage teacher candidates to make their own intrapersonal connections to arts-based practice.

A reflective component comprised of in-class journaling and group activities woven into the daily agenda of my methods course, provides us with theoretical and practical opportunities to reconsider our recurring narratives in relation to multiple sign systems, 
including those associated with the arts. For example, using Milgrom's (1992) practice of responding metaphorically to a text with "rough, untutored shapes" (p. 10) of colored paper, we tear events from our pedagogical past to color and shape our teaching narratives of the present and future. A small red speck expresses a teacher candidate's nonexistent part in elementary school art. Scraps of blue paper ripped into a set of flowing tears, captures another teacher candidate's fear of drawing in her high school years. A cache of cascading coils in green, represents a third teacher candidate's early painting for the backdrop of a oneact award-winning scene. According to Milgrom (1992), the significance of the forms reside, not in their geometric, figural, or abstract shapes, but in the meaning that the maker ascribes to them.

To ponder former teachers who have influenced our current practice, we sketch, doodle, draft, and react to the significance of remembered events (Colvin, 1994). A gradenine tutor's passion for performance, emerged in a teacher candidate's recent interest in reader's theatre. A different teacher candidate's fascination with visuals, stemmed from a fifth grade instructor's studies in storied mural screens. Another teacher candidate's reluctance to move from print to paint, originated from an elementary art teacher's assignment of the grade of "C". The above two exercises, as well as the many others that I include in the reflective component, begin with a journal entry that then moves into sites of both small group and whole class discussion. The main goal is always to query the past of where we are now to the possibilities of where we can be. Although, in this paper, I locate our work in relation to the reflective component in arts-based novel study for adolescent readers, the process of narration via early recollections holds potential for examining our 
teaching lives in relation to other modes of expression found in such areas as math, technology, and physical education. But that is the substance of another paper.

\section{In Conclusion}

As Connelly and Clandinin (1999) state, "The memory now, of the event then, is intimately tied to the narrative paths we have followed" (p. 95). In the quarrying of my three recollections, I have been both the artist and the picture (Adler, 1958), selecting, interpreting, representing and expressing. Enduring influences, adrift in the sights and sounds of former years, have paved my pedagogical course in the currents of time. Underneath my classroom praxis lives the narrative of significant events, motivating and influencing me to reformulate and pursue my goals in language arts education. The melding of reading and art. A clash of color. A concert in red and green. Lodged in my teaching narrative are the original footings of my praxis, poured from my responses to two teachers' classes.

Narrated into the daily realities of my teaching life, I reenter my pre-service classroom more conscious of the origins of my arts-based praxis, settling on the study of novels for adolescent learners. Adler asserted that the most fundamental purpose of memory for an individual...is to offer guidance for action in the present and future (Clark, 2002). Informed by my teaching narrative, crafted in the backdrop of remembered times, I venture forth to address the effects of arts-based learning on the teacher candidates' theoretical and classroom practices. Working together, we will have numerous opportunities to recast and reintegrate the many pieces of our narratives into an arts-based praxis. A more informed construction of our recurring narratives, kindled by the illumination of early recollections, will play an integral role. 


\section{References}

Abbs, P. (2003). Against the flow. New York: Routledge Falmer.

Adler, A. (1927). Understanding human nature. NY: Fawcett Premier.

Adler, A. (1930). The education of children. Chicago: George Allen \& Unwin.

Adler, A. (1932). Technique of treatment. In H. Ansbacher, \& R. Ansbacher, (Eds.), Superiority and Social Interest: A Collection of Later Writings (pp.191-201). New York:

W.W. Norton.

Adler, A. (1956). Psychology of use. In H. Ansbacher, \& R. Ansbacher, (Eds.), The Individual Psychology of Alfred Adler (pp. 204-235). New York: Harper \& Row.

Adler, A. (1958). The Practice and Theory of Individual Psychology.

Patterson, NJ: Littlefield, Adams.

Alexander, E. (1971). Forward. In C. Moustakas. Personal growth (pp. ix-xiv).

Cambridge, MA: Howard A. Doyle.

Amabile, T. (1989). Growing up creative: Nurturing a lifetime of creativity. Buffalo, NY: The Creative Education Foundation.

Ansbacher, H. (1947). Adler's place in the psychology of memory. Journal of Personality, 15, 199-207.

Avi. (1990). The True Confessions of Charlotte Doyle. New York; Avon.

Boardman, K. (1991). Educational biographies of feminist teachers. (Report No. CS 212 898). Boston, MA: Conference on College Composition and Communication (ERIC Document Reproductive Service No. EDU 337 767). 
Britzman, D. (1986). Cultural myths in the making of a teacher: biography and social structure of teacher education. Harvard Educational Review, 56, 442-456.

Buckelew, M. (2003) The value of art in the English classroom: Imagination, making the tacit visible. English Journal, 92, 49-55.

Bussert-Webb, K. (2001). I won't tell you about myself, but I will draw my story. Language Arts, 78, 511-519.

Caswell, R. (2005). A musical journey through John Steinbeck's The Pearl: Emotion, engagement, and comprehension. Journal of Adolescent and Adult Literacy, 49, 62-67.

Clark, A. (2002). Early recollections: theory and practice in counseling and psychotherapy. New York: Brunner-Routledge.

Clark, A. (2004). On the meaning of color in early recollection. Journal of Individual Psychology, 60, 141-154.

Colvin, C. (1994). Using images from literature to compose a philosophy for teaching. Journal of Reading, 37, 682-683.

Connelly, F., \& Clandinin, D. (1988). Teachers as curriculum planners. New York: Teaches College Press.

Connelly, F., \& Clandinin, D. (1990). Stories of experience and narrative inquiry. Educational Researcher, 19, 2-14.

Connelly, F., \& Clandinin, D. (1999). Shaping a professional identity. New York: Teachers College.

Cosner, L., (2002). Psyography: Alfred Adler. Retrieved May 14, 2007, from http://faculty.frsotburg.edu/mbradley/psyography/alfredadler.html

Costello, C. (1993). Graffiti-A positive approach. Notes Plus, October, 6-7. 
Csikszentmihalyi, M. (1991). Flow: The psychology of optimal experience. New York: Harper Perennial.

Dinkelman, T. (2003). Self-study in teacher education: A means and ends tool for promoting reflective teaching. Journal of Teacher Education, 54, 6-18.

Eickstein, D., \& Baruth, L. (1996). The theory and practice of life-style assessment. Dubuque, IA: Kendall/Hunt.

Eisner, E. (1992). The misunderstood role of the arts in human development. Phi Delta Kappan, 73, 591-595.

Fleishman, P. (1998). Whirligig. New York: Dell Laurel Leaf.

Fredricksen, E. (2000). Muted colors: Gender and classroom silence. Language Arts, 77, 301-307.

Gardner, H. (1999). Intelligence reframed: Multiple intelligences for the $21^{\text {st }}$ century. New York: Basic Books.

Gilbert, J., \& Morawski, C. (2005). Stress coping in elementary school children: Exploring life style applications. Journal of Individual Psychology, 61, 314-328.

Gilles, C., Andre, M., Dye, C., \& Pfannenstiel, V. (1998). Talking about books: Constant connections through literature - using art, music, and drama. Language Arts, 76, 67-75.

Greene, M. (1991). Texts and margins. Harvard Educational Review, 61, 27-39.

Greene, M. (1995). Releasing the imagination: Essays on education, the arts, and social change. San Francisco: Jossey-Bass Publishers.

Grey, L. (1954). A comparison of the education philosophy of John Dewey and Alfred Adler. The American Journal of Individual Psychology, 11, 71-80. 
Harner, L., \& Romer, N. (1992). Reading and autobiographies in twos. Liberal Education, 78, 18-23.

Hayden, T. (1995). The tiger's child. New York: Avon Books.

Hestor, R. (2004). Early memory and narrative. Journal of Individual Psychology, 60, 338-347.

Hinton, S. (1967). The outsiders. New York: Puffin.

Hynes, M. (2003). Assessing growth in reading through multiple sources of information. English Quarterly, 35, 11-18.

International Reading Association. (1999a). Adolescent literacy: A position statement. Newark, DE: International Reading Association.

International Reading Association. (1999b). High-stakes assessments in reading: A position statement. Newark, DE: International Reading Association.

Jersild, A. (1955). When teachers face themselves. NY: Teachers College Press.

Kirby, A. (1991). Narrative and the self. Indianapolis, IN: Indiana University Press.

Laird, S. (1988). Reforming “woman's true profession: A case for "feminist pedagogy" in teacher education. Harvard Educational Review, 58, 449-463.

Leggo, C. (1995). Storing the word/storying the world. English Quarterly, 28, 5-11.

Leland, C., \& Harste, J. (1994). Multiple ways of knowing: Curriculum in a new key. Language Arts, 71, 337-345

Maniacci, M., Shulman, B., Griffith, J., Powers, R., Sutherland, J., Duchman, R., \& Schneider, F. (1998). Early recollections: Mining the personal story in the process of change. Journal of Individual Psychology, 54, 451-479. 
Marlett, P. (2004). The use of alternative texts in physical education. Journal of Adolescent and Adult Literacy, 41, 376-381.

McKay, R., \& Kendrick, M. (2001). Children draw their images of reading and writing. Language Arts, 78, 529-533.

Milgrom, J. (1992). Handmade midrash: A guide for teachers. New York: The Jewish Publication Society.

Morawski, C. (1995). Teachers' early recollections of learning to read: Applications in reading teacher education in the content areas. Reading Research and Instruction, 34, 315331.

Morawski, C. (2006, May). Kite strings of fictional realities: Palettes dark and light. Paper presented at the meeting of the $2^{\text {nd }}$ Congress of Qualitative Inquiry, UrbanaChampaign, IL.

Morawski, C., \& Palulis, P. (in press). Auto/ethno/graphies as teaching lives: An aesthetics of difference. Journal of Curriculum Theorizing.

Mosak, H. (1958). Early recollections as a projective technique. Journal of Projective Techniques, 22, 302-311.

Mosak, H. (1995). Adlerian psychotherapy. In Corsini, R., \& Wedding, D. (Eds.), Current psychotherapies. Itasca, IL: F. E. Peacock.

Murata, R. (1997). Connecting the visual and verbal: English and art for high school sophomores. English Journal, 86, 44-48.

Noddings, N. (1984). Caring: A feminist approach to ethics and moral education. Berkeley, CA: University of California Press.

O’Keefe, G. (1976). Georgia O'Keefe. New York: The Viking Press. 
Pearson, M., \& Wilborn, B. (1995). Ann Richards: An Adlerian Psychobiography. Individual Psychology, 51, 266-281.

Pillemer, D. (2001). Momentous events and the life story. Review of General Psychology, $5,123-134$.

Riley, C. (1995). Color Codes. Hanover, NH: University Press of New England.

Rosenblatt, L. (1978). The reader, the text, the poem. Carbondale, Il.: Southern Illinois University Press.

Rosenblatt, L. (1980). Literature as exploration. London: Heinemann.

Schneider, M. \& Stone, M. (1998). Narrative: Creating stories. Journal of Individual Psychology. 54, 413-415.

Seuss, D. (1947). McElligot's Pool. New York: Random House.

Short, K., Kauffman, G., \& Kahn, L. (2000). "I just need to draw”: Responding to literature across multiple sign systems. The Reading Teacher, 54, 160-171.

Smith, P. (2001). Inquiry cantos: Poetics of developmental disability. Mental Retardation, 39, 379-390.

Sullivan, A., (2000). Notes from a marine biologist's daughter: On the arts and science of attention. Harvard Educational Review, 70, 211-227.

Sweeney, T. (1981). Adlerian counseling. Muncie, IN: Accelerated Development.

Thorpe, C. (1987). The growing teacher: How to become the teacher you've always wanted to be. Individual Psychology, 43, 246-249.

Underwood, W. (1987). The body biography: A framework for student writing. English Journal, 76, 44-48. 
Verger, D., \& Camp, W. (1970). Early recollections: Reflections of the present. Journal of Counseling Psychology, 17, 510-515.

Warren, (1982). The relationship between early recollections and behavior patterns. Individual Psychology: The Journal of Adlerian Theory, Research and Practice, 38, 223-237.

Watts, R. (1998). The remarkable similarity between Roger's core conditions and Adler's social interest. Journal of Individual Psychology, 54, 4-9.

Watts, R. \& Pietrazak, D. (2000). Adlerian "encouragement" and the therapeutic process of solution-focused brief therapy. Journal of Counseling and Development, 78, 442-447.

Whitin, P. (2002). Leading into literature circles through the sketch-to-stretch strategy. The Reading Teacher, 55, 444-450. 